\title{
Use of the 2nd generation TRAK human assay did not improve prediction of relapse after antithyroid medical therapy of Graves' disease
}

\author{
T Zimmermann-Belsing, B Nygaard ${ }^{1}, \AA$ K Rasmussen and U Feldt-Rasmussen \\ Department of Endocrinology, Rigshospitalet, and ${ }^{1}$ Department of Endocrinology, Herlev Hospital, University of Copenhagen, Denmark \\ (Correspondence should be addressed to Ulla Feldt-Rasmussen, Department of Endocrinology PE-2132, University Hospital Rigshospitalet, \\ Blegdamsvej 9, DK-2100 Copenhagen, Denmark; Email: ufeldt@rh.dk)
}

\begin{abstract}
Objective: Antithyroid drug treatment (ATD) is used world-wide in the treatment of thyrotoxicosis in patients with Graves' disease (GD). The main problem is a relapse rate of 30 to $50 \%$ within 2 years after the treatment has stopped. The measurement of thyrotropin receptor antibodies (TRAb) in serum has been used to confirm the diagnosis of GD in selected patients with a diagnostic specificity of 70 to $90 \%$. However, in predicting the recurrence of thyrotoxicosis after discontinuing ATD it has been of little value. The aim of this study was to evaluate the ability of TRAb measured by the more sensitive recombinant human TSH receptor method to predict risk of recurrence of GD after discontinuing ATD.

Materials, patients and methods: One hundred and twenty nine patients with newly diagnosed GD were included. Of these, 58 had relapse of hyperthyroidism in a follow-up of at least 11 months (median 18 months, range 11-49) after discontinuing ATD. In 122 Graves' patients TRAb were measured at the time of diagnosis and in all patients when discontinuing ATD by a competitive radioreceptor assay using recombinant human TSH receptors (TRAK human assay).

Results: We found an increased diagnostic specificity (99\%) compared with the old TRAK porcine assay. The predictive values of a positive and negative test in relation to the prediction of a relapse of GD were found to be only $55 \%$ and $62 \%$ respectively when using a cut-off level of $1.5 \mathrm{IU} / \mathrm{l}$, and the predictive value of a positive test decreased to $49 \%$ and of a negative test to $60 \%$ at a lower cut-off limit (1 IU/l).

Conclusion: Our study confirms that the new TRAK human assay had a superior diagnostic sensitivity in comparison with the old TRAK porcine assay. Despite the higher diagnostic sensitivity of the TRAK human method, we could not find any improvement of predictive values for relapse of hyperthyroidism in the measurement of TRAb at the end of ATD.
\end{abstract}

European Journal of Endocrinology 146 173-177

\section{Introduction}

Autoantibodies directed against the thyrotopin (TSH) receptor are responsible for the hyperthyroidism of Graves' disease (GD) (1-3). TSH receptor antibodies (TRAb) affect the activity of thyroid cells either by binding to the TSH receptor, activating adenylate cyclase resulting in an increase in cyclic adenosine- $3^{\prime} 5^{\prime}$ monophosphate (cAMP) (TSH receptor binding stimulating antibodies (TSAb)), or by binding to the receptor and blocking the availability to TSH (TSH receptor blocking antibodies (TBAb)) (1-3). TRAb are detected either by their capacity to inhibit the ability of radiolabeled TSH to bind to receptor preparations (TBII: TSH-binding inhibitory immunoglobulins) or by their stimulatory functional effects on thyroid tissue in vitro (TSAb) $(4,5)$.
Until a few years ago the validated commercial routine assay for the detection of TRAb was the competitive radio receptor assay (RRA) using porcine thyroid membrane extracts (1st generation TRAK porcine assay). This assay was widely used, although only about 70 to $90 \%$ of GD patients at diagnosis had detectable levels of TRAb in the serum (3-5). The measurement of TRAb was determined to be of some clinical value in confirming the diagnosis of GD but was of little value in the estimation of its prognosis (6). The introduction of the recombinant human TSH receptor has allowed the development of a new RRA (2nd generation TRAK human assay), a chemiluminescence assay in coated tube format (7). The TRAK human assay has a superior diagnostic sensitivity for GD (713) but the predictive value of relapse is controversial $(12,13)$, as it was for the old assay $(6,14)$. 
The aim of this study was, therefore, to evaluate the ability of TRAb, measured by the new 2nd generation TRAK human assay to predict the risk of recurrence of GD after discontinuing antithyroid drug therapy (ATD).

\section{Materials and methods}

\section{Patients}

In order to predict the risk of recurrence of GD after ATD, 129 patients with newly diagnosed GD were included and followed (Table 1). Graves' patients from the Departments of Endocrinology at Herlev University Hospital $(n=97)$ and at Copenhagen University Hospital, Rigshospitalet $(n=32)$ were included. The criteria for GD were hyperthyroidism with or without ophthalmopathy and a diffuse uptake on a ${ }^{99 \mathrm{~m}} \mathrm{Tc}$ pertechnetate scintigraphy. The criteria establishing hyperthyroidism were clinical symptoms, increased serum concentrations of total thyroxine $\left(\mathrm{T}_{4}\right)$, increased total triiodothyronine $\left(\mathrm{T}_{3}\right)$ and decreased TSH (Table 1).

The Graves' patients were treated with ATD (thiamazole or propylthiouracil) with no addition of L-thyroxine (ATD) for 18 months (6-30) (median (range)) and followed for 18 months (11-49) after discontinuing ATD. At the time of diagnosis, only 122 patients with GD had concentrations of TRAb measured (Table 1). The diagnostic specificity was calculated based on 37 normal controls (23 female, median age: 38 years $(24-73)$ ), and a cut-off limit of $1.5 \mathrm{IU} / \mathrm{l}$ was used (8). At the time of discontinuing ATD, all 129 Graves' patients had serum concentrations of TRAb measured, and the sensitivity and specificity of TRAb to predict relapse were calculated.

\section{Thyroid functional tests}

At Rigshospitalet, serum concentrations of TSH (reference range: $1.5-2.7 \mathrm{mU} / \mathrm{l}$, lower detection limit of
$0.01 \mathrm{mU} / \mathrm{l})$ were measured by time resolved fluoroimmunoassay, (hTSH Ultra, Wallacoy, Turku, Finland), $\mathrm{T}_{4}$ by was measured by fluorescence polarisation immunoassay $\left(\mathrm{IM}_{\mathrm{X}}^{\mathrm{R}}\right.$, Abbott Laboratories Diagnostics Div., Illinois, USA) $(60-140 \mathrm{nmol} / \mathrm{l})$, and $\mathrm{T}_{3}$ by microparticle enzyme immunoassay $\left(\mathrm{IM}_{\mathrm{X}}^{\mathrm{R}}\right.$, Abbott) (1.5$2.7 \mathrm{nmol} / \mathrm{l})$. At Herlev University Hospital, serum concentrations of $\mathrm{T}_{4}$ (reference range: $56-129 \mathrm{nmol} / \mathrm{l}$ ) and $\mathrm{T}_{3}(1.0-2.5 \mathrm{nmol} / \mathrm{l})$ were determined by Kodak Amerlite (Amersham UK, Amersham, Bucks, UK) and serum TSH was determined by Kodak Amerlite TSH30 (Amersham UK) with a lower detection limit of $0.005 \mathrm{mU} / \mathrm{l}$.

\section{2nd generation TRAK}

The DYNOtest TRAK human (BRAHMS Diagnostica, Berlin, Germany) measures antibodies quantitatively against the human TSH receptor. Detection is based on the ability of TRAb to prevent the binding of labeled TSH to the TSH receptor. The TRAb concentration in the patient sample was calculated from a standard curve of a sample with a known TRAb concentration. The assay was calibrated according to WHO standard 90/672. In this study, and as the manufacturer recommends, TRAK human values below 1.0 IU/l were defined as negative, values above $1.5 \mathrm{IU} / \mathrm{l}$ as positive, and patients with values between 1.0 and $1.5 \mathrm{IU} / \mathrm{l}$ were monitored for the development of autoimmune thyroid disease (8). The intra-assay variation of 3 samples of 1.35, 6.2 and $29 \mathrm{IU} / \mathrm{l}$ was 15, 4 and 5\% respectively, and the interassay variation of 3 samples of $1.5,20.8$ and $29.1 \mathrm{IU} / \mathrm{l}$ was 15,8 and $8 \%$ respectively (12).

\section{Statistics}

The data are presented as medians with ranges in brackets and analyzed non-parametrically using the

Table 1 Subject characteristics and clinical parameters of 129 Graves' patients with positive TRAb at the time of diagnosis. Median and ranges are given.

\begin{tabular}{lll}
\hline & $\begin{array}{c}\text { Graves' patients not } \\
\text { developing relapse }\end{array}$ & $\begin{array}{c}\text { Graves' patients } \\
\text { developing relapse }\end{array}$ \\
\hline Number & 71 & 58 \\
Male/Female & $10 / 61$ & $10 / 48$ \\
Age at time of entering the study (years) & $46(21-74)$ & $38^{*}(20-76)$ \\
Family history (number with positive) & 18 & 20 \\
Time of treatment (months) & $18(6-30)$ & $18^{\text {ns }}(10-30)$ \\
Follow-up time after discontinuing ATD (months) & $18(11-49)$ & $10(1-42)$ \\
Time until relapse after discontinuing ATD (months) & & $0.01^{\text {ns }}(<0.01-0.07)$ \\
Thyrotropin at diagnosis (mU/I) & $0.01(<0.01-0.05)$ & $283^{\text {ns }}(146-594)$ \\
Thyroxine at diagnosis (nmol/I) & $268(97-608)$ & $7.9^{\text {ns }}(2.2-19.8)$ \\
Tri-iodothyronine at diagnosis (nmol/l) & $7.1(2.0-19.0)$ & $6.4^{\text {ns }}(0.3-41.4)$ \\
TRAb at diagnosis (IU/l) & $8.6(0.4-36.9)$ & $1.4^{\text {ns }}(0.3-5.1)$ \\
TRAb when discontinuing ATD (IU/l) & $1.1(0.1-68.6)$ & \\
${ }^{*} P<0.05 ;$ ns, not significant. & &
\end{tabular}


Mann-Whitney test. The predictive value (PV) of a positive (TRAb $>$ cut-off limit) and a negative (TRAb $<$ cut-off limit) test was estimated as follows: $\mathrm{PV}_{\mathrm{pos}}=$ number of TRAb positive patients with relapse as a fraction of the total number of TRAb positive patients; $\mathrm{PV}_{\text {neg }}=$ number of TRAb negative patients without relapse as a fraction of the total number of TRAb negative patients.

\section{Results}

At diagnosis, 116 patients were TRAb positive $(>1.5 \mathrm{IU} / \mathrm{l})$, and 6 patients were TRAb negative $(<1.5 \mathrm{IU} / \mathrm{l})$; with a cut-off limit of $1.0 \mathrm{IU} / \mathrm{l}, 118$ patients were TRAb positive and 4 were TRAb negative (Table 2). For the normal controls, 36 were TRAb negative and $1 \mathrm{TRAb}$ positive $(\mathrm{TRAb}=1.6 \mathrm{IU} / \mathrm{l})($ Table 2$)$. The diagnostic specificity of TRAb (>1.5 IU/l) in serum $(n=122)$ was $99 \%$ and the sensitivity was $86 \%$, while at a cut-off limit of $1.0 \mathrm{IU} / \mathrm{l}$, the specificity was similar at $99 \%$ and the sensitivity was $90 \%$ (Table 2).

At the time of discontinuing ATD, 51 patients were $\mathrm{TRAb}$ positive and 78 were TRAb negative $(<1.5 \mathrm{IU} / \mathrm{l})$; using a cut-off limit of $1.0 \mathrm{IU} / \mathrm{l}, 74$ were TRAb positive and 55 were TRAb negative (Table 3 ). Fifty-eight of the patients had recurrence of GD and 71 remained euthyroid. Recurrence developed after 10 months (1-42) (median (range)) after discontinuing ATD. The patients with relapse were younger compared with those without relapse. The mean $\mathrm{T}_{4}$ level at diagnosis was $268 \mathrm{nmol} / \mathrm{l}(97-608)$ (median (range)), mean $\mathrm{T}_{3}$ was $7.1 \mathrm{nmol} / \mathrm{l}(2.0-19.0)$ and TSH was suppressed $(0.01 \mathrm{mU} / \mathrm{l}(<0.01-0.05))$ in non-relapsing patients and were not different from relapsing thyrotoxic Graves' patients (Table 1). Both $\mathrm{T}_{4}$ and $\mathrm{T}_{3}$ were normalized after 3 months of therapy. No significant changes were found in TRAb at time of diagnosis or when discontinuing ATD between non-relapsing and relapsing Graves' patients (Table 1).

The serum levels of TRAb measured at the time of diagnosis and at the time of discontinuing ATD were

Table 2 Diagnostic specificity and sensitivity of the 2nd generation TRAK human assay using a cut-off limit of $1.5 \mathrm{IU} / \mathrm{l}$ or $1 \mathrm{IU} / \mathrm{l}$.

\begin{tabular}{llcr}
\hline & \multicolumn{1}{c}{$\begin{array}{c}\text { Graves' } \\
\text { patients }\end{array}$} & $\begin{array}{c}\text { Normal } \\
\text { controls }\end{array}$ & Number \\
\hline TRAK $>1.5 \mathrm{IU} / \mathrm{I}$ & 116 & 1 & 117 \\
TRAK $<1.5 \mathrm{IU} / \mathrm{I}$ & 6 & 36 & 42 \\
Number & 122 & 37 & 159 \\
Diagnostic specificity & $116 / 117=99 \%$ & & \\
Diagnostic sensitivity & $36 / 42=86 \%$ & & \\
TRAK $>1$ IU// & 118 & 1 & 119 \\
TRAK $<1$ IU/I & 4 & 36 & 40 \\
Number & 122 & 37 & 159 \\
Diagnostic specificity & $118 / 119=99 \%$ & & \\
Diagnostic sensitivity & $36 / 40=90 \%$ & & \\
\hline & & &
\end{tabular}

Table 3 Prognostic evaluation of the 2nd generation TRAK human assay using a cut-off limit of $1.5 \mathrm{IU} / \mathrm{l}$ or $1 \mathrm{lU} / \mathrm{l}$.

\begin{tabular}{llcr}
\hline & \multicolumn{1}{c}{ Relapse } & No relapse & Number \\
\hline TRAK $>1.5 \mathrm{IU} / \mathrm{I}$ & 28 & 23 & 51 \\
TRAK $<1.5 \mathrm{IU} / \mathrm{I}$ & 30 & 48 & 78 \\
Number & 58 & 71 & 129 \\
Specificity & $48 / 71=68 \%$ & & \\
Sensitivity & $28 / 58=48 \%$ & & \\
Positive predictive value & $30 / 51=55 \%$ & & \\
Negative predictive value & $48 / 78=62 \%$ & & \\
TRAK $>1$ IU/I & 36 & 38 & 74 \\
TRAK $<1$ IU/I & 22 & 33 & 55 \\
Number & 58 & 71 & 129 \\
Specificity & $33 / 71=47 \%$ & & \\
Sensitivity & $36 / 58=62 \%$ & & \\
Positive predictive value & $36 / 74=49 \%$ & & \\
Negative predictive value & $33 / 55=60 \%$ & & \\
\hline
\end{tabular}

independent of whether the GD patients had recurrence or not. The predicitve value of the presence of TRAb $>1.5 \mathrm{IU} / \mathrm{l}\left(\mathrm{PV}_{\text {pos }}\right)$ at the time of discontinuing ATD $(n=$ $129)$ in relation to relapse was $55 \%$ and $\mathrm{PV}_{\text {neg }}$ was $62 \%$ (Table 3). When using a cut-off limit of $1.0 \mathrm{IU} / \mathrm{l}$, $\mathrm{PV}_{\text {pos }}$ decreased to $49 \%$ and $\mathrm{PV}_{\text {neg }}$ to $60 \%$.

\section{Discussion}

Until recently, measurement of TRAb had to rely on assays using porcine antigen (TRAK porcine assay). Costagliola and co-workers (7) in a trial of 86 patients with untreated GD and 282 healthy individuals showed a diagnostic sensitivity of $98.8 \%$ and a specificity of $99.6 \%$ using TRAK human, with a cut-off limit of $1 \mathrm{IU} / \mathrm{l}$ (7). In the present study, we have confirmed that the TRAK human assay increased the specificity for diagnosis of GD from $80 \%$ (TRAK porcine assay) to nearly $100 \%$, which is clearly superior to the TRAK porcine assay $(5,7-11)$. The increase in diagnostic specificity, however, was not accompanied by an improvement in the prediction of relapse/remission at the end of ATD in GD, and the calculated predictive values were very similar to those reported in an earlier meta-analysis (6) based on reports from the TRAK porcine assay. Whether the conflicting results are due to differences in the methodology of the TRAb methods, TRAb heterogeneity, patient selection or other factors is at present not clarified, since some populations seem to demonstrate higher predictive values of serum TRAb concentrations after ATD (6, 13-18). Thyroids of some of the TRAb positive patients with GD might not have the ability to respond with hyperthyroidism because of iodine deficiency of the thyroid due to previous ATD or because of autoimmune damage of the thyroid generated during the treatment period. These phenomena might be one of the reasons why TRAb might not be the ideal predictor 
in some GD populations. In our study, the follow-up period was at least 11 months, which should be sufficient to exclude the possibility of overlooking hyperthyroidism in TRAb positive patients. It has been suggested that the rate of fall of TRAb is faster in the second 6 months of ATD in those patients who will eventually achieve long-term remission (19); this was, however, in contrast to another study (20), but different assay systems were used in these studies. However, Maugendre and Massart (11) suggested that the measurement of TRAb values between 6 and 12 months after the start of ATD might be too early to predict relapses in GD. It has also been suggested that relapsing Graves' patients at the time of diagnosis and/or at time of discontinuing ATD had higher TRAb (TRAK porcine) compared with GD patients without relapse (19); we could not confirm this in our study using the TRAK human assay (Table 1).

Autoantibodies directed to the TSH receptor might either mimic the stimulating action of TSH or inhibit the action of the hormone, and the heterogeneous nature of TRAbs is well recognized (21). TSAb is pathogenic of GD, but serum from most Graves' patients probably contains both TSAb and TBAb activities, and the clinical effect may depend on the relative concentration and affinity of the predominating antibody $(1-5)$. However, TBAb seem to be rare in Caucasians and more common in Asians (22).

The choice of treatment in patients with GD seems to be, at least partly, dependent on the country in which the patient has been treated (15). ATD is mainly used in Europe and Japan while radioiodine is often preferred in the USA (15). However, some endocrinologists in the USA suggest ATD (12). In the majority of European countries the patients are treated for 1-2 years and thereafter they are followed-up by measurement of thyroid hormones (23). However, some endocrinologists monitor the treatment by measurement of the TRAb level $(12,24)$. The main problem is a relapse rate of between 30 and $50 \%$ within 2 years after the treatment has stopped and a variety of different predictors of relapse have been looked for such as age, goiter size, radioactive iodine uptake, degree of ophthalmopathy, serum concentrations of thyroglobulin $(\mathrm{Tg})$, anti-thyroid peroxidase (anti-TPO), anti-Tg or TRAb, HLA DR typing, $\mathrm{T}_{3}$ suppression test or ATD (25). Even in various combinations these indices have proven unsatisfactory as reliable predictors of remission $(13,14,16-18,21$, 23, 26-33). This was confirmed in the meta-analysis of data from 10 prospective studies in the literature, which showed a statistically significant difference between the number of relapses in patients with or without TRAb at the end of ATD treatment. The predictive value of both a positive and a negative test was low and $25 \%$ of patients were misclassified (6) but others have disagreed with this conclusion (12).

In forecasting the transient neonatal syndromes in the offspring of women with autoimmune thyroid disease, the TRAK porcine assay was found to be reliable $(23,34)$.

In principle, the bioassay might be preferable in the prediction of relapse of GD after ATD because it is possible to measure both stimulating and blocking antibodies separately; however, the assays are cumbersome and expensive for routine purposes and in practice are not superior to other methods $(3-5,12,23)$.

In conclusion, our study confirms that the new TRAK human assay had a superior diagnostic sensitivity in comparison with the old TRAK porcine assay. Despite the demonstrated higher sensitivity of the TRAK human method, we could not find any improvement of predictive values for relapse or remission by measuring TRAb at the end of ATD in GD.

\section{Acknowledgements}

We thank BRAHMS Diagnostic for providing the TRAK kits as well as the laboratory technicians Lisbeth Kirkegaard, Betty Fischer, Ulla K Hansen and colleagues for handling the patient samples and TRAb measurements. This work received financial support from Agnes and Knut Mørks Foundation.

\section{References}

1 Smith BR, Mclachlan SM \& Furmaniak J. Autoantibodies to the thyrotropin receptor. Endocrine Review 19889 106-121.

2 Weetman AP \& McGregor AM. Autoimmune thyroid disease: further developments in our understanding. Endocrine Reviews $199415788-830$.

3 Rapoport B, Chazenbalk GD, Jaume JC \& McLachlan SM. The thyrotropin (TSH) receptor: interaction with TSH and autoantibodies. Endocrine Reviews 199819 673-716.

4 Morgenthaler NG. New assay systems for thyrotropin receptor antibodies. Current Opinion in Endocrinology and Diabetes 19996 251-260.

5 Gupta MK. Thyrotropin-receptor antibodies in thyroid diseases: advances in detection techniques and clinical applications. Clinica Chimica Acta $20002931-29$.

6 Feldt-Rasmussen U, Schleusener H \& Carayon P. Meta-analysis evaluation of the impact of thyrotropin receptor antibodies on long term remission after medical therapy of Graves' disease. Journal of Clinical Endocrinology and Metabolism $1994 \mathbf{7 8}$ 98-102.

7 Costagliola S, Morgenthaler NG, Hoermann R, Badenhoop K, Struck J, Freitag D et al. Second generation assay for thyrotropin receptor antibodies has superior diagnostic sensitivity for Graves' disease. Journal of Clinical Endocrinology and Metabolism $1999 \mathbf{8 4}$ 90-97.

8 Schott M, Feldkamp J, Bathan C, Fritzen R, Scherbaum WA \& Seissler J. Detecting TSH-receptor antibodies with the recombinant TBII assay: technical and clinical evaluation. Hormone and Metabolic Research 200032 429-435.

9 Giovanella L, Ceriani L \& Garancini S. Clinical applications of the 2nd generation assay for anti-TSH receptor antibodies in Graves' disease. Evaluation in patients with negative 1st generation test. Clinical Chemistry Laboratory Medicine $20013925-28$.

10 Massart C, Orgiazzi J \& Maugendre D. Clinical validity of a new commercial method for detection of TSH- receptor binding antibodies in sera from patients with Graves' disease treated with antithyroid drugs. Clinica Chimica Acta 2001304 39-47. 
11 Maugendre D \& Massart C. Clinical value of a new TSH binding inhibitory activity assay using human $\mathrm{TSH}$ receptors in the follow-up of antithyroid drug-treated Graves' disease. Comparison with thyroid stimulating antibody bioassay. Clinical Endocrinology $20015489-96$.

12 Davies TF, Roti E, Braverman LE \& DeGroot LJ. Thyroid controversy-stimulating antibodies. Journal of Clinical Endocrinology and Metabolism $1998 \mathbf{8 3} 3777-3785$.

13 Schleusener H, Schwander J, Fischer C, Holle R, Holl G, Badenhoop K et al. Prospective multicentre study on the prediction of relapse after antithyroid drug treatment in patients with Graves' disease. Acta Endocrinologica 1989120 689-701.

14 Wilson R, McKillop JH \& Thomson JA. The prognostic value of thyrotropin receptor antibody (TRAb) levels in Graves' disease. Annals of Clinical Biochemistry 199027 601-602.

15 Wartofsky L, Glinoer D, Solomon B, Nagataki S, Lagasse R, Nagayama Y \& Izumi M. Differences and similarities in the diagnosis and treatment of Graves' disease in Europe, Japan, and the United States. Thyroid 19911 129-135.

16 Schleusener H, Feldt-Rasmussen U \& Carayon P. Do thyrotropin receptor antibodies (TRAb) predict relapse after antithyroid drug treatment of Graves' disease. Experimental and Clinical Endocrinology $1994102162-166$.

17 Benker G, Reinwein D, Kahaly G, Tegler L, Alexander WD, Fassbinder J \& Hirche $\mathrm{H}$. Is there a methimazole dose effect on remission rate in Graves' disease? Results from a long-term prospective study. The European Multicentre Trial Group of the Treatment of Hyperthyroidism with Antithyroid Drugs. Clinical Endocrinology $199849451-457$.

18 Maugendre D, Gatel A, Campion L, Massart C, Guilhem I, Lorcy Y et al. Antithyroid drugs and Graves' disease - prospective randomized assessment of long-term treatment. Clinical Endocrinology $199950127-132$.

19 Michelangeli V, Poon C, Taft J, Newnham H, Topliss D \& Colman P. The prognostic value of thyrotropin receptor antibody measurement in the early stages of treatment of Graves' disease with antithyroid drugs. Thyroid $1998 \mathbf{8} 119-124$.

20 Takasu N, Yamashiro K, Komiya I, Ochi Y, Sato Y \& Nagata A. Remission of Graves' hyperthyroidism predicted by smooth decreases of thyroid-stimulating antibody and thyrotropin-binding inhibitor immunoglobulin during antithyroid drug treatment. Thyroid $200010891-896$.

21 Bech K. Immunological aspects of Graves' disease and importance of thyroid stimulating immunoglobulins. Acta Endocrinologica Supplement $1983 \mathbf{1 0 3}$ 5-38.

22 Jordan NJ, Rinderle C, Ashfield J, Morgenthaler NG, Lazarus J, Ludgate M \& Evans C. A luminescent bioassay for thyroid blocking antibodies. Clinical Endocrinology 200154 355-364.
23 Feldt-Rasmussen U. Analytical and clinical performance goals for testing autoantibodies to thyroperoxidase, thyroglobulin, and thyrotropin receptor. Clinical Chemistry $1996 \mathbf{4 2} 160-163$.

24 Nagayama Y, Izumi M \& Nagataki S. The management of hyperthyroidism due to Graves' disease in Japan in 1988. Endocrinology 198936 299-314.

25 Feldt-Rasmussen U, Glinoer D \& Orgiazzi J. Reassessment of antithyroid drug therapy of Graves' disease. Annual Reviews in Medicine $1993 \mathbf{4 4} 323-334$

26 Laurberg P, Buchholtz Hansen PE, Iversen E, Eskjær Jensen S \& Weeke J. Goitre size and outcome of medical treatment of Graves' disease. Acta Endocrinologica $198611139-43$.

27 Ikenoue H, Okamura K, Sato K, Kuroda T, Yoshinari M, Tokuyama T, Nakagawa M \& Fujishima M. Prediction of relapse in drug-treated Graves' disease using thyroid stimulation indices. Acta Endocrinologica 1991125 643-650.

28 Weetman AP, Ratanachaiyavong S, Middleton GW, Love W, John R, Owen GM et al. Prediction of outcome in Graves' disease after carbimazole treatment. Quarterly Journal of Medicine $1986 \mathbf{5 9}$ 409-419.

29 Kawamura S, Kishino B, Tajima K, Mashita K \& Tarui S. Serum thyroglobulin changes in patients with Graves' disease treated with long term antithyroid drug therapy. Journal of Clinical Endocrinology and Metabolism 198356 507-512.

30 Feldt-Rasmussen U. Serum thyroglobulin and thyroglobulin autoantibodies in thyroid disease. Allergy $1983 \mathbf{3 8} 369-387$.

31 Wilson R, McKillop JH, Henderson N, Pearson DW \& Thomson JA. The ability of the serum thyrotrophin receptor antibody (TRAb) index and HLA status to predict long-term remission of thyrotoxicosis following medical therapy for Graves' disease. Clinical Endocrinology $198625151-156$.

32 Alexander WD, McLarty DG, Robertson J, Shimmins J, Brownlie $\mathrm{BE}$, Harden RM \& Patel AR. Prediction of the long-term results of antithyroid drug therapy for thyrotoxicosis. Journal of Clinical Endocrinology and Metabolism 197030 540-543.

33 Yamada T, Takasu N, Sato A, Aizawa T \& Koizumi Y. Pituitarythyroid feedback regulation in patients with Graves' disease during antithyroid drug therapy. Journal of Clinical Endocrinology and Metabolism $1982 \mathbf{5 4} 83-88$.

34 Laurberg P, Nygaard B, Glinoer D, Grussendorf M \& Orgiazzi J. Guidelines for TSH-receptor antibody measurements in pregnancy: results of an evidence-based symposium organized by the European Thyroid Association. European Journal of Endocrinology $1998139584-586$.

Received 30 March 2001

Accepted 15 October 2001 